\title{
Medium Aevum, le Moyen-Âge, Middle Ages
}

\section{Ruth Morse}

\section{(2) OpenEdition \\ Journals}

Electronic version

URL: http://journals.openedition.org/shakespeare/923

DOI: 10.4000/shakespeare.923

ISSN: 2271-6424

\section{Publisher}

Société Française Shakespeare

\section{Printed version}

Date of publication: 1 November 2002

Number of pages: 129-148

\section{Electronic reference}

Ruth Morse, "Medium Aevum, le Moyen-Âge, Middle Ages ", Actes des congrès de la Société française Shakespeare [Online], 19 | 2002, Online since 01 November 2007, connection on 06 May 2019. URL http://journals.openedition.org/shakespeare/923 ; DOI : 10.4000/shakespeare.923 


\section{S H A K E S P E A R E \\ \& L E M O Y E N - Â G E}

Société Française Shakespeare

Actes du Congrès de 2001

* * *

Textes réunis et présentés par

Patricia DORVAL

publiés sous la direction de Jean-Marie MAGUIN 


\section{MEDIUMAEVUM, LE MOYEN-ÂGE, MIDDLE A GES}

If we are to believe the $O E D$, and what scholar does not?, the first appearance in English of «the middle age» in the sense of a historical period comes in a sermon on 1 Timothy 15 : «It is a perplex't question in the School, (and truly the Balance in those of the middle age, very even) whether if Adam had not sinned, the son of God had come into the world, and taken our nature and our flesh upon him» ${ }^{1}$. The middle age, le moyen âge, comes into English as both singular and plural, and by the early eighteenth century English has settled, happily, although inconsistently, for the plural ${ }^{2}$. The citation is from Donne, and when he preached that sermon, Shakespeare had been dead for two years ${ }^{3}$. The $O E D$ could have cited Camden some years earlier, but my point is precisely not to identify a defining moment, or occurrence, but to consider the difficulties created by posing the question.

Scholars are alert to the dangers of anachronism in thinking about Shakespeare's inheritance from and attitude to «the» Middle Ages, but less, perhaps, alert to the dangers of our regular recourse to the $O E D$. If we start with a phrase or its non-existence, we confront difficulties greater than tracing it might seem to imply. That is, if we go back in time, looking for the first occurence of something, we will find it. But the «it» that we find may not, in its own context, be the «it» we were looking for. The nonexistence of a word does not, of course, disprove the existence of a 
concept for an early period, but nor does the existence of the word attest the concept, or concepts, in this case, of a historical period. Shakespeare was most unlikely to have had either the word or words designating our concept or concepts like ours. The first part of this paper will explore this assertion. The second will look at attitudes towards «the» or «a» past or pasts in some of Shakespeare's immediate predecessors or contemporaries. Then I will sketch Shakespeare's practice, before, briefly, concluding with a return to the initial questions.

\section{«The Former Age»}

The idea of «a» middle, from which one is just recovering, has served in many times and places - wherever, no doubt, some claim to restoring former glory has been at issue. Proclaiming not just «the new» but its superiority was, after all, a recent, Modernist shock, as the Modernists themselves boasted. That did not make it true, of course. In retrospect there always seem to be more continuities than appeared at the time. To invoke the quarrels between Ancients and Moderns, by contrast, is to remember that long-lived locus communis of decline from a distant Golden Age. Spenser's celebration of «Dan Chaucer, well of English undefyled / On Fames eternall beadroll worthie to be fyled» (The Faerie Queene (1595) IV.2.32) echoes earlier returns to the purity of Cicero, and Cicero's own Republican values might find a modern echo in Mrs Thatcher's intellectually bankrupt appeal to «Victorian Values» - with, perhaps, equal anachronism. For it is an essential observation that whatever it is that is legitimated, it is not a rebirth direct from the well, not even a resuscitation. It is an appeal to the preeminence of origin, to aristocratic descent. This argument is a genealogy, but it is a genealogy with a difference. Between us and the good old days there is always darkness and decline.

Therefore, the idea of restoration appeals to arguments of prior superiority. Revival of poetry, language (that is, philology), art, architecture, of learning more generally, of ideas of history, of political structures or legal systems, above all, theology, the return to the pure source of the Gospels, - these seven topic headings identify areas where claims to renovation, renewal, re-formation were focussed by different men at different times in different countries. Their strengths as description, which imply strengths as demonstration, as argumentative force, grow at different rates, depending upon subject, time, and place. They do have things in common, but by and large they have different meanings 
depending upon when and where they were used. One cannot simply trace a phrase back in time and write that history, as historians have begun to insist ${ }^{4}$. All of these «re-'s» turn on that unspecified area of darkness I have already invoked, but that is only to observe that now is a contrast to some time ago. My seven areas are neither ages nor stages, and I believe it is a coincidence that there are seven, but they do not, because they cannot, coalesce into a consistent idea of a Middle Ages until ideas of history, of change, establish themselves ${ }^{5}$.

So our rediscovery of the growth of ideas requires a double perspective: what authors thought they were doing at the time, and, obviously, our binocular vision in retrospect, a retrospect which needs to attend to those once-taken-for-granted metaphors which may reveal so much. OED2 cites Donne and Sir Henry Spelman, the antiquarian, who uses the plural «middle ages» ${ }^{6}$. The problem about dictionary definitions is always that the dictionary cannot discriminate the complex and different usages and associations it cites, or plot the dynamics of historical semantics where «the middle ages» changes, slightly but significantly, its connotations. Donne invokes the learning of the schools with approval; so does Spelman. Petrarch, first among Renaissance equals, meant something rather different. At the very least «middle ages» moves; it expands. The phrase is not the same in different cultural spaces, in the larger context of different kinds of periodization. Nor can the $O E D$ much help us with the linguistic situation of multiple languages. «Medium Aevum» and «le moyen age» antedate usage in English, but there, too, problems arise which have not always been fully appreciated in surveys of the question. This is not a matter of defining exactly when it or they happened, as does Godefroid Kurth. He attempts to clarify something which seems to him, in a «historicist» as well as positivist age, obviously to have existed. But there are problems with that point of view, problems with the idea that we can define something into clarity, and thus into existence, like Anselm's proof for the existence of God, who cannot lack anything, and therefore cannot lack existence. Like that other «unit idea», «courtly love», also coming into prominence at the end of the nineteenth century, «middle ages» is problematic at the very least because if we pose it as a question we impose it as a thing?

Very briefly, then, the developments of ideas of middle ages because I must begin by emphasizing their plurality - have been traced back in history by slightly redefining a concept (a period in a middle) which already existed, but existed within the context of late-classical, if I 
may be permitted that periodization, beliefs in seven ages, four ages and three ages, that is, seven of history, four of man and the world, three of time $^{8}$. This inheritance from the ancient world and the first centuries of Christianity, from Orosius and Augustine (whose ideas seem to have been more of an interim than a middle), include the increasingly doubtful, but always to be resuscitated, idea of a last age, or at least a next-to-last age. These systems sit more or less uneasily together, and, given the ways they permeate the textual culture of Europe, remain legitimate for reference. That is, one has to be in a position to look back over a terrain which has at least three divisions in it, not two : the lost period ; the period of losing ; early recovery (dawn) ; now ; hereafter, which may be the end. Augustine saw himself between the Incarnation and the end of time, but was never willing to say when that end might come. Not «middle», then, but «interim», «between».

If we allow Petrarch to guide us, the beginning of the idea of recovery from something - barbarity, darkness - between Antiquity and «now» was his own, fourteenth century, when he began to situate himself against something, appropriating an available phrase, which he slightly reorientated (he also had to use the blanket-condemnation move, of course, in order to erase ifs, buts, and exceptions). But it took about two centuries for the variety of «middles» differently invoked by poets, lawyers, philologists, historians and so on and so forth, to coalesce in the ideas of a historical middle ages with which we are familiar ${ }^{9}$. In what we call the Middle Ages the idea of «middle age» implied beginnings and ends, which worked very well in parallel with one human life or the life of worldly time. That is, if we are living at the end of time, the middle must be what immediately precedes us or, more problematically, the middle must be now. But it works much less well if one has to be specific. And Petrarch is just as short on dates as his successors were to continue to be ${ }^{10}$.

There is a further complication, which is that this emulation, this reorienting in time, to push the «middle» forward to «just before us», is one of the repetitions which attempts to erase through competition. Thus the emulative move, the renovatio, by asserting, or re-asserting, the jump over the intervening period (now redefined), insists that previous attempts to go back to the origins, to the undefiled well, were not only incomplete, but even failures which reinforced the length and strength of the benighted middle.

The idea of the Middle Ages, like that of the novel, is something which comes to look clear in retrospect, but which emerges slowly over a 
long time, and with many variations. As the novel grows from the romance, so the Middle Ages give birth to the renaissance. And as the romance was rediscovered by Warton and the eighteenth century, so one of the ways we know that «the middle ages» has established itself is when scholars, accepting its existence, begin to revalorise it. One might accept the apparent designation, but appropriate it as a positive rather than a negative evaluation: no longer the Gothic barbaric, but the romantic and, it must be said, the cradle of the national. For Garrick and others Shakespeare becomes «the bard», which associates him with the singer at the hypothesized medieval court. This is not the place to trace this claim in detail ; but some indications will give a sense of the rhythm of the story. One extra complexity is that the story of the story is a case of scholars looking for their own period concerns, their ancestors, what I have already called a genealogy of aristocratic descent (like Warton's attempt to establish a mediaeval phase of English poetry), so they tend only to find a part of the whole. W. P. Ker was still using «middle age», and the coinages «mediaeval», «mediévale», «moyen-âgeux» are relatively recent. The spelling ligature «ae» is significant in this context, and has aroused passions similar to Holofernes' assaults on the monster Ignorance, or those over the orthography of the name of the author of the Aeneid ${ }^{11}$. If we are looking for Dark Ages we will find them. Their slow retreat is part of this story, too.

The Dark Ages and the Middle Ages - or the Middle Age - used to be the same ; two names for the same period. But they have come to be distinguished, and the Dark Ages are now no more than the first part of the Middle Age, while the term mediaeval is often restricted to the later centuries, about 1100 to 1500 , the age of chivalry, the time between the first Crusade and the Renaissance. ${ }^{12}$

As evaluative descriptive words go, «renaissance» has had a long run of praise, just as barbarism has remained its shadow opposition. But this pairing forgets the usual story about «renaissance», too, as a midnineteenth-century neologism. A slight digression is important here. I say «the usual story» because «renaissance» is usually traced to writing about art, beginning perhaps with T. A. Trollope's Summer in Brittany (1840), becoming current in Ruskin's Stones of Venice (1851), normalizing in Arnold's Culture and Anarchy (1861) and Pater's almost contemporary 
Renaissance (1873). Arnold comments on his change of spelling, anglicizing «renaissance» to «renascence» ${ }^{13}$. If we press on this preference for the loan-word, we discover that there was already an English way of going about things. There was, after all, scholarship on «the revival of learning» which is still used by J. E. Sandys in his magisterial History of Classical Scholarship ${ }^{14}$. My point here is that the metaphor is of resuscitation, a revivification and not rebirth. The master word of the semantic field is restoration, which, within a much larger but equally genealogical narrative of Protestant triumphalism, presupposes something rather different from the idea of rebirth, which may itself allude to a dead metaphor of baptism, of something rather more, if I may put it this way, Christian in the sense of new dispensation. That is, it is the English usage which distinguishes itself from re-birth, a metaphor which Sandys traces back to what we would call the Carolingian Renaissance ${ }^{15}$. I speculate that there is a not-very-hidden agenda here in which periodization is at the service of God's Englishmen and their national and confessional superiority to the still-Catholic continent.

From a twenty-first century perspective, I do not think the Middle Ages are clear until what we parlously call the Renaissance is at least well established, and at most in some sense over. More importantly, neither «period» has agreed duration, but attitudes to problems such as twelfthcentury renaissances, high or low middle ages have been taken as problems to be solved rather than themselves evidence of changes in ideas about time and periodization. Only with the development of a historical sense which is itself dateable, that is, after Vico, can we begin to ask questions such as Kurth's. An article asking whether women had a Middle Ages would cast an interesting light on the famous title of whether they had a Renaissance. The current shift in usage from Renaissance to Early Modern in English studies is testimony to many things, one of which is an intriguing repetition, a polemic which attaches them to us as the locus of our antiquity, and severs us both from all medieval history or literature. It is an emulative, competitive attempt at devaluing and erasure. If Boccaccio is a problem, how much more so is Petrarch ? From a seventeenth-century perspective, in Latin, in French, and in English, ideas of middle ages are just coming to be, descriptions which fit different aspects of the past at different times and in different ways. Shakespeare himself, after the Restoration, comes to belong much more to that repudiated «middle» than we always allow. We will not find a systematic 
approach to the past ; there cannot be, as there was not yet systematic history.

So have we arrived at an impasse, from which we cannot emerge because we cannot employ the terms around which the debate itself is launched ? If Shakespeare cannot have had either the word meaning our concept, or our concept under any other word, is there anything we can do to save the appearances? If he did not have our sense of time, or of periodization, he certainly had something, although it may have been neither methodologically consistent or theoretically explicit. If we can get this a little clearer it may also help with those anachronistic clocks and leather aprons.

\section{Bare ruin'd choirs, Great bases for eternity}

Ruins matter in this story; they were all around, evidence of the passing of time, the disintegration of monuments in stone or brass. Roman roads linked English cities; Saxon and Norman fortifications defined English towns; abandoned villages witnessed to the ravages of natural pestilence, famine, and plague; the dilapidation (in the literal sense) of selected monuments of the Old (meaning «former») Religion marked the countryside while they enriched some of its denizens. This layering of change encourages ideas of cycles, not necessarily ideas of «a» middle. Bacon's Novum Organum pursues this idea of cycles, times of the advancement of learning with great troughs of darkness in between. Cycles, as I have stressed above, are not linear development, and that double-referential descriptive possibility survives and thrives. The growth of the idea of the Middle Ages must be linked to the growth of ideas of history, of the treatment of units of time, which are now so familiar to us that, like the nation-state, they seem unavoidable.

Among Shakespeare's contemporaries, and younger contemporaries, the antiquarians (not historians in our sense) and lawyers begin to build pictures of succeeding periods in which there is or are a middle age, or middle ages. Camden's Remains of 1605 can hardly avoid some engagement with succeeding times, if not with what we call chronology ; indeed, he begins with a geographical celebration of his island which reaches back in that emulative move to assign its greatness to its aristocratic pedigree.

I will perform that I promised, in handling nothing seriously; and therefore I will bring you in 
some poets, to speak in this behalf for me and will begin with old Alfred of Beverley, who made this for Britain in generall, which you must not read with a censorious eye ; for it is, as the rest I will cite, of the middle age, having heretofore used all of more ancient and better times in another work.

But lest I should seem over prodigal in the praise of my countrymen, I will only present you with some few verses in this behalf; and first this Latin Rithme of the middle times, in praise of the English Nation, with some close cautions.

... I will only give you a taste of some of middle age, which was so overcast with dark clouds, or rather thick fogs of ignorance, that every little spark of liberal Learning seemed wonderful ; so that if sometimes you happen of an uncouth word, let the time entreat pardon for it, whenas all words have their times... ${ }^{16}$

The third quotation offers the immediate satisfaction of apparent recognition, but in context Camden is emphasizing how exceptional English learning was, and his poets might be taken to demonstrate continuity (Joseph of Exeter on Troy, for example) rather than rupture ; only after parading insular Latin Learning does he go on to quote Chaucer, «our English Homer» (342). But, to complicate matters entirely, he then refers to all his examples as «our ancient Poets» (344), thus making synonyms of «ancient» and «middle», and using his terms indiscriminately in praise and blame. Chaucer himself writes a poem we know as «The Former Age», but in it invokes the long-ago Golden, not the previous ${ }^{17}$.

These writers of ancient middle time, to use contemporary vocabulary, all worked in Latin and in English, as of course did Donne with whom I started, because education was Latinate, and Theology and Law were preeminently cited in Latin continuities. A learned discourse is also safer, much safer, if one is to write or think about dynastic or religious restoration - one would not call it disruption. Something must have been happening to a sense of England as both part of Europe and as distinctly itself, something which is part of what we call, also retrospectively, nationalism, but in which we might see a kind of «kingdomism» crossing what is not yet sectarianism. From this point of view the Middle Ages 
were pan-European in ways which were not only decadent or a decline, in terms of an increasingly corrupted Church, but Imperial, in a sense in which the isles of Brut were subjected to the country of Aeneas. Yet this in turn leads us to consider that in the desire to push back the origins of British church reform (not yet protestantism, a parallel case), erasing any sudden divide which might be deemed innovation rather than restoration also suggested the potential contradiction of a need for continuity, issues important in King John and Henry VIII. One could write a new history in which England kept the faith throughout benighted times, in the face of foreign opposition.

This last point is useful, because it suggests more than one way of dealing with the periodization of the past. British chroniclers tend to speak of reigns since the Conquest; one can equally well find a political «middle ages» which runs from the fall of Rome to the fall of Constantinople, as the sixth edition of the Dictionary of the French Academy decides (but not until 1835). But one need not. If one then turns to Du Cange, the areas of study I mentioned earlier are represented, but they are never made into one coherent system ${ }^{18}$.

\section{A month old at Cain's birth but not five weeks yet}

Dull's riddle about the moon is a timely reminder, a reminder that time, in agricultural former ages, was largely a matter of days and months, seasons of the year as registered in the almanac. Time meant different things to characters of different status, in different places, and the insufficiencies of historians could have serious consequences, such as the invasion of France. As You Like It's ages belong to a discourse of analogy and relationship, not to a discourse of history. Rosalind knows the world's age and speaks of «the foolish chroniclers of that age» with cavalier lack of exactness (IV.1.85-98), as Jacques knows the cycles of men's ages, but there is no specificity in either of their references. Transforming their commonplaces into learned disquisitions is rather the work of editors and scholars, and uncomfortably close to Holofernes.

If, then, Shakespeare has no «middle ages», how does Shakespeare talk about time, about ages, how does he periodize ? Are his characters consistent, or do they vary in the options they use ? Is the speaker of the Sonnets special ? Is there any sense of a placement in time, or contrasts with «now»? Do my prolegomena help clarify those anachronistic clocks and guns by calling «anachronism» itself into question? We need to analyze the vocabulary of time, and of time passing. Unsurprisingly, 
«Shakespeare» is tacit about passing time, even if we equate the man with the voice of the sonnets. Shakespeare's characters characterize time depending on who they are, when, and where. It might be thought that stage practice might help ; although there may be evidence of togas among costumes, there is none of "ancient» English dress, and characters make enough reference to the varieties of contemporary vestimentary differences, by individual taste, rank, or local custom, to reduce time passing to a kind of sumptuary spectrum. References to architecture may seem more promising, but what is one to do with the monastic ruins around Aaron ${ }^{19}$ ?

Francois Laroque has emphasized Shakespeare's representations of time «as something concrete and material»; let me press that point. A metaphor or a metonym appeals to the imagination and offers a way around particularity. Nothing is less identical than «likeness». Festival offers an alternative to time in the sense in which $I$ have been discussing it here. The speakers of Prof. Laroque's paradoxical references are themselves situated in pasts which are not exact, but which do allow for ranges of reference ${ }^{20}$.

Is there a consistent, non-festive, vocabulary of time passing? From $O E D$ to Concordances, then, the search continues, but each occurrence is in a character's mouth, and is therefore to be discriminated accordingly. What follows can easily be checked in Marvin Spevack's indispensable volume, though one must remember here, too, that one searches in a lack of semantic field ${ }^{21}$. Shakespeare's usual meaning for «past» is «previous», and he speaks only rarely of «the past» (as in Sonnet 123), which is of indefinite distance and duration. «History» is close to French «histoire», and often means story, although story which may be true - like Cesario's sister's. The «former golden days» which are invoked in 3 Henry VI, (III.3.7) utilise a set expression for subsequent decline, but given that the speaker is Margaret of Anjou there is likely to be a certain irony. I have already mentioned that Rosalind, in her personage of a pert boy, knows «the world is almost six thousand years old» (As You Like It, IV.1.95) and Jacques, in his own person, knows about the Ages of Man, but there is no sign that the three or four or seven Ages of the World were useful to Shakespeare. In the Vale of Evesham Falstaff finds nostalgia, but the decline is entirely personal. In Shakespeare's characters' perspectives there is often no middle distance - in the sonnets time is now, recent, or eternity. This, too, is a personal rather than a historical time. Cleopatra likewise juxtaposes now, then, eternity. There is a comfortable vagueness 
about time, as there is about space. It is a little like one, two, three infinity or hither, thither, yon. That is because there is no decadence, no darkness, no falling off to recoup. Overall, one can say that in small units Shakespeare has hours (undivided into clock minutes) and days, months and years, but his precisions are usually imprecise, functioning. only to give a sense of specificity without tying him to one, as in the double timescheme of Othello or the sense of haste in The Tempest. Similarly, although there is the occasional ninth of next month or eleventh of this, Shakespeare's «date», like «period» is a fixed point rather than a numbered or labelled day, further modified by the necessities of the equally elastic two hours' traffic.

Shakespeare, like Montaigne, uses «age», but to mean «a long period of time». He never uses century to mean one hundred years, and «thousand» almost always indicates a very big number. If he makes few comments on regnal or ecclesiastical dating, or the calendar (which is a synomyn for the almanac), his characters invoke the commonest festivals : Hollowmas and Holyrood Day (Richard II, V.1.80 and I.1.52 and Measure for Measure, II.1.120) ; Michaelmas, which might have arisen for renting, moving, or hiring only twice (Merry Wives and 1 Henry IV, II.4.54 where it is part of a calculation of age). Church festivals are less apparent than tenacious custom would have led one- to expect, though I shall have something to say about Gower's view of them in a moment. St David's Day (but not St Andrew's); St George's ; Ophelia sings of St Valentine ; there are about four references to Lent/lenten; and only one to Easter (Romeo and Juliet) ; two of the three references to Christmas have to do with the games or shows associated with that holiday; and, of course, King Harry's veterans get their wounds on St Crispin's Day. His father's desire to take the cross recalls that it is fourteen hundred years since Christ lived, which is remarkably exact given Shakespeare's usual practice (I.1.26). Dynastic continuity was not just a concern for the House we call Lancaster, but remained so in England as in Scotland. In fact the greatest (and great here is very small) concentration of apparently exact dating falls in Canterbury's speech in Henry V, I.2, where it might be argued that the calculations are all so much smoke to encourage the invasion of France ${ }^{22}$. Nonetheless, Canterbury is arguing from legal evidence as contained in charters, demonstrating, were it necessary, continuity with the past in the sense in which legal precedent represents it. In passing it should be remarked that if Shakespeare was a Catholic he was remarkably discreet about his character's attitudes to the cycles of the years. Reformed «feast 
days» are not quite the old Holy Days renamed, but whatever the arguments about observance, they held the calendar in place ${ }^{23}$. Shakespeare is equally even-handed about the pre-reformed clergy, or clergy elsewhere : Canterbury and Wolsey may be movers, but Friars Lawrence and Francis are good men.

Like everyone around him, Shakespeare knew that what we call Classical Antiquity was different from us, but that is not different in kind from the awareness of twelfth- or even ninth-century educated men. In historical time, in which medieval men argued the parallels between pagan and Old Testament chronologies, there was a fluidity which was not resolved - because, of course, it was not resolvable. One could sense that Rome declined into Italy, despite the advantages of Christianity, but Shakespeare is neither a philosopher nor a historian, and he might be said to use what is available rather than to reflect much upon it, as indeed Cymbeline suggests. «Antique» means «extremely old» for Shakespeare, as «antiquity» means very long ago, including «Antique Rome» Henry $V$ (Chorus, prologue to Act V), where the distinction is between the pagan and the Christian cities, as indeed it is when Horatio uses it.

Of the possible practices which might be thought to offer «measure», it would be very difficult to show that Shakespeare had affiliations with the new learning (as it called itself), despite the inkhornery in Love's Labour's Lost. He is not concerned with changes in handwriting, or spelling, and if he himself plays with some of the innovations of Early Modern English such as auxiliary «do» («They that have pow'r to hurt, and will do none, / Who do not do the thing they most do show», Sonnet 94), or retains conservative features such as the genitive without «s» (as in «some lady trifles» in Antony and Cleopatra), even if he mixes third person singulars in -eth and in -es, there is nothing special in that. If the only artist he mentions by name is Julio Romano, he mentions him in the surprising context of the freshly painted statue of Hermione in Winter's Tale. The place where we might expect to find a middle ages in Shakespeare is in the legendary Britain of Kings Cymbeline and Lear. But we do not.

Ancient English authors offer the most promising avenue. of enquiry into Shakespeare's possible concepts of the past. English changed. It is in philology that we can find most awareness of English as unstable through time. It would appear that Shakespeare (or Shakespeare and Fletcher) knew something about older forms of English, but here, too, there are problems, since it may be Shakespeare's older contemporary, Spenser, 
whom they imitate. Spenser was one among many to insist on the threefold-founder story through which a modern vernacular could establish itself. Spenser had already created a precedent, as well as a method, for inventing, or perhaps reviving, an archaizing style, in The Shepeardes Calender and, to a less extent, his Fairie Queene, and Shakespeare learned from him. Shakespeare knew two at least of those founding fathers, Chaucer and Gower. In The Two Noble Kinsmen the speaker of the Prologue says :

We pray our play may be so [modest], for I am sure It has a nobler breeder and a pure, A learned, and a poet never went More famous yet 'twixt Po and silver Trent.

Chaucer, of all admired, the story gives ;

There, constant to eternity, it lives.

If we let fall the nobleness of this

And the first sound this child hear be a hiss, How will it shake the bones of that good man

And make him cry from under ground, «Oh, fan

From me the witless chaff of such a writer

That blasts my bays and my famed works makes lighter

Than Robin Hood !»

(Prologue 9-21) ${ }^{24}$

The evidence of Pericles is rather more interesting ${ }^{25}$. Shakespeare brings Gower back from dust : «from ashes auncient Gower is come» announces the poet-chorus. Vocabulary, syntax, and morphology contribute to a cod English which is certainly intended to make style give an impression of pastness. «Ember eves» and «holy days», verbs of motion with «to be», a slightly higher incidence of subject-object-verb order, phrases such as «I tell you what mine authors say», obsolete vocabulary or vocabulary used in old-fashioned senses (I wis, certainly ; peer, wife ; benison ; derne ; attent) ; careful absence of the innovative auxiliary «do»; plurals, infinitives, and pasts expressed by the suffix -en (including incorrectly, «he spoken can» for «he knew how to speak»); prefix $y$ - to indicate the preterite ( $y$-slacked, $y$-ravished). These marked words tend to come in groups, further to call attention to themselves, and sometimes the thickness of these evocations becomes quite startling, as «All perishen of men, of pelf / Ne aught escapend but himself» (Act II, Prologue) - and it is quite clear, looking at a sequence of editions, that not all editors have seen what 
Shakespeare would be at, and have corrected or «clarified» Gower's speech ${ }^{26}$. Philology has recurred in this talk at several moments, and it is with philology that I would close ; Gower seems to me to suggest that Shakespeare (or Shakespeare + Fletcher) had some awareness of language change through time. That is not, however, awareness that Chaucer or Gower belong to a Middle Ages.

Henry VIII is nicely mixed in its references to men of religion, and to religion, and its characters refer to «the law» as if there were one thing, and it immemorial; as so often in Shakespeare there is something for everyone, no sharp definitions, and no moment of revolution. Rather, like other plays, it succeeds in its balance and ambiguities by structural repetitions which elevate ambition and envy over the dangers of discussing doctrine. The question of Reform is necessarily of moment, but it is absorbed in Wolsey's and Gardiner's human and personal machinations, and is made to seem contingent to the play's human dramas. Relations between King Henry, Cardinal Wolsey, and Cranmer capitalize on a series of stresses, not all of which are religious, and none of which describe a rupture. What we see is Shakespeare exploiting up-to-date arguments without explicitly naming them. Henry dismisses Wolsey's exaction of a tax because there is no legal precedent, that is, no evidence of custom (I.2.88-94), and Buckingham appeals similarly to the law, and then accepts its judgement, if not its justice ; when he compares his fate to his father's he makes no distinction of time. Here we see something quite like Pocock's descriptions of varying attitudes to the law in the sixteenth century ${ }^{27}$. Since the action of the play is resolutely present for its participants, the eternal question is betraying one's master, as Wolsey himself eloquently recognizes. So the multiple accusations against Cardinal Wolsey are that he is a «new» man, and has no guide through his upbringing, and that, at the same time, he is not only an upstart, but backed by a foreign power (Henry VIII, II.2.54), and that he plays both ends against the middle (the Dukes' accusations in III.2). He is finally ruined when Henry sees his ambition. Our hindsight emphasizes Rome or Latin as «Catholicism» at II.4.233-5 or III.1.40-50, when it is «Lutheranism» which is the marked position, e.g. III.2.99, as is Wolsey's accusation, repeated later by Gardiner, that Cranmer is a heretic. Yet the king swears «By my Holydame» and by «God's blest mother» (V.1.116, 153 and V.2.32). The most important ambiguity is Katherine's vision of the heavenly banquet, which is not even necessarily Christian, let alone sectarian. If anything the play merely refers to the arguments about continuity and discontinuity in 
the scene of Cranmer's trial (V.2), where he gets the better of Gardiner's accusations of novelty $(114)$, sectarianism $(104,114)$, disloyalty $(114,116)$. There is a reference to Limbo Patrum, which may be a confusion with «Lime House», «limbs», and the license which attends the rejoicing over Elizabeth's christening (V.3.59-65), and Cranmer the visionary sees the newly-christened baby achieving company with the saints. If the play ends on the word Holy-day, that is an old-fashioned, not a «medieval» touch. There is, however, one crucial caveat in the preceding analysis : if Cyrus Hoy and Jonathan Hope are right, the legal examples I have quoted are probably Shakespeare's, while the religious ones are Fletcher's ${ }^{28}$.

A suggestion of Prof. Sukanta Choudhury's offers a promising avenue for further study. If Shakespeare sometimes archaizes his Romans; in order to suggest an uprightness, even an old-fashioned kind of honour, he often contrasts their vulnerability to more politically-via-wise powerbrokers. This is not only visible within the Roman plays, where we recognize dangerous men through their rhetorical fireworks, but also in the contrasts between the Trojans and the Greeks in Troilus and Cressida. Prof. Choudhury speculates that if we follow this difference to its logical conclusion, there is a sense in which Shakespeare's Romans turn out, stylistically, to be «older» than his Greeks ${ }^{29}$. This strikes me as a fine reminder that Shakespeare wrote for the theatre, and that his dramatic effects emphasize relativity rather than absolute chronology. That he has ideas of sequence, but not a systematic sense of historical periodization, now seems to me unsurprising. It is one of the many ways in which his discretion about religious and national issues in his kingdom does not abide our opening question.

\section{Whose Middle Ages ?}

Shakespeare and the Middle Ages ? From our perspective there is no reason to avoid such a subject, for Shakespeare read Chaucer, perhaps Malory, certainly a series of Italian authors we may (but may not) wish to categorize as medieval. Medievalists themselves enjoy discussing their own shifting frontiers ; when they discuss Dante, Petrarch, Boccaccio, it may only be the middle poet who is fully renaissance (given Boccaccio's conservative Latin compositions), while C. S. Lewis famously argued that what Chaucer really did was remedievalize the story of Troilus. Medieval historians have historically used «middle» to push back «dark». But then, of course, medievalists are always contending with the prejudice that the renaissance is a sign of progress, and therefore A Good Thing. Periodizing 
along modern lines will not work. And there is one further caveat to be remembered. I began with an $O E D$ citation from John Donne, «Anglican Divine»; what he meant refers to university theologians before religion was reformed. No more, perhaps, than that. There was no great divide. If we insist on erecting one, it will be neither a matter of language nor literature. It is not even one of law or history, although the dynastic changes which open and close the English history plays might seem to be candidates. It is rather theology : the divisions of the kingdoms. On the continent the sixteenth century saw civil wars, terror, and uneasy peaces, but the vocabulary the participants used is not ours ${ }^{30}$. Shakespeare's tact, his ambiguities and evasions, are so remarkable that they leave room for scholars to reopen debates over his own beliefs. But even in All is True/King Henry VIII Wolsey is a man (if a bold bad one [II.2.431]), as Cranmer is a man, and neither is an allegory. Time passes, and Shakespeare writes about its passage, but he did not, because he could not, share our concept of «the middle ages ${ }^{31}$.

Ruth MORSE Université Paris VII

\section{NOTES}

1 From «A Second Sermon Preached at White-Hall», April 19. 1618, quoted from The Sermons of John Donne, ed. George R. Potter and Evelyn M. Simpson, Berkeley and Los Angeles, University of California, 1953-, vol. I, p. 303. Donne then rehearses the schoolmen's arguments with approval.

${ }^{2}$ See G.S. Gordon, «Medium Aevum and The Middle Age», Society for Pure English Tract $\mathrm{n}^{\circ} 19$, Oxford, Clarendon Press, 1925, p. 1-25. Division or fragmentation can be an advantage, of course, and suggests a category a little more tentative than the singular.

${ }^{3}$ An earlier citation from Thomas James, Bodley's first librarian, was said to appear in A Treatise on the Corruption of Scripture, Councels, and Fathers, Advt. to the Christian Reader, *3: «The open or secret wrongs done unto Fathers, auncient, middle-aged, or moderne writers by the Papists» (1611, not used by 
$O E D$ ). Gordon quotes this from Paul Lehmann, Vom Mittelalter und von der lateinischen Philologie des Mittelalters: Quellen und Untersuchen zum lateinischen Philologie des Mittelalters, vol. 1, Munich, 1914, p. 9-10.

${ }^{4}$ And it is significant that the research on this question stems from the article by Gordon cited in note 1 and then repeats the surveys of subsequent scholars. See Nathan Edelman, «The Early Uses of Medium Aevum, Moyen Age, Middle Ages», Romanic Review, 19, 1938, p. 3-25 ; then Jürgen Voss, «Le Problème du Moyen Âge dans la pensée historique en France : XVIe-XIXe siècle», in Revue d'histoire moderne et contemporaine, 24, 1977, p. 321-40, which is a French summary of the conclusion to his Das Mittelalter im historischen Denken Frankreichs. Untersuchungen zur Geschichte des Mittelalterbegriffes und der Mittelalterbewerung von der zweiten Hälfte des 16. bis zur Mitte des 19. Jahrhunderts, Munich, W. Fink Verlag, 1972, and which was criticized in detail by Jean-Michel Dufays, «Medium tempus et ses équivalents : aux origines d'une terminologie de l'âge intermédiaire», Pensiero Politico, 21, 1998, p. 237-49.

${ }^{5}$ One might compare the idealizing description in such influential scholars as the Belgian medievalist Godefroid Kurth, Qu'est-ce que le moyen âge?, which was often reprinted from its first appearance in 1897.

${ }^{6}$ «But thus the eldest and newest expositors are wholly for me, many also (and of the best of them) of the middle ages», De non temerandis ecclesiis, a tract of the rights and respect due to churches, London, ?second edition, expanded, 1646 [not in edition of 1613] (ULC Bb*.9.40), Appendix, p. 40, rather differently quoted by Edelman, p. 6 .

${ }^{7}$ As a parallel argument on another of the terms which built the agreed picture of the middle ages, see John C. Moore, «Courtly Love : a problem of terminology», Journal of the History of Ideas, 40, 1979, p. 621-32.

${ }^{8}$ J. A. Burrow, The Ages of Man : a Study in Medieval Writing and Thought, Oxford, Clarendon, 1986 is the exemplary discussion of this subject, and, as he points out, «middle age» had a positive connotation (p. 8-11).

${ }^{9}$ The lawyers' middle ages cannot be like Petrarch's, because they are the source of custom, and therefore to be cherished. The locus classicus is J. G. A. Pocock, The Ancient Constitution and the Feudal Law : A Study of English Historical Thought in the Seventeenth Century, Cambridge, Cambridge University Press, 1957.

${ }^{10}$ The pin-pointing move has always caused difficulties, because periodizing is always reductive. Peter Burke discusses the salient moment of Petrarch's climbing Mount Ventoux to look at the view in his The Renaissance Sense of the Past, London, 1963.

"The fulminations against «rackers of orthography» in Love's Labour's Lost (e.g. V.1) give us a sense of what the astute might mock, but one doesn't, after all, mock a dead letter. How funny the scenes must have been is clear in Shakespeare's 
recycling them for Rosalind, for Benedick and for Dogberry, and, perhaps most startlingly, for Hamlet.

${ }^{12}$ This is the once well-kown opening of W. P. Ker's The Dark Ages, London, Nelson, 1904, in the series «Periods of European Literature». form».

${ }^{13}$ «I have ventured to give to the foreign word Renaissance an English

${ }^{14}$ The second volume is subtitled From the Revival of Learning to the End of the Eighteenth Century (in Italy, France, England, and the Netherlands), Cambridge, Cambridge University Press, 1908. As early as William Roscoe's Life of Leo X, London, 1805 (and frequently reprinted) we find the concatenation «restoration» / «revival» / «reformation», e.g. vol II. p. 253, 279, vol. 111 p. 135 , $146,192,222,257$. He attributes to Warton the orientation of his historical «story». I am grateful to Prof. Gareth Stedman-Jones for the suggestion that I look at Roscoe, and to Prof. Richard Tuck for the reference to Sandys.

15 «Aurea Roma iterum renovata reliascitur orbi», from Modoin on Charles' innovations in learning, and he traces «renaissance» to a translation from Italian «rinascimento», first remarked Furetière's dictionary (1708), History of Classical Scholarship, vol. II, p. 2-3.

${ }^{16}$ William Camden, Remains Concerning Britain, intro. Leslie Dunkling, Trowbridge, 1974 [London, 1870] ; text of 1605, p. 7, 18, 337. It should be stressed that all the poetic citations are in Latin.

17 «A blysful lyf, a paisible and a swete, / Ledden the peples in the former age» (1.1-2). The title is Skeat's. See also Davis, et al., Chaucer Dictionary s.v. former and Middle English Dictionary, which derives former from $\mathrm{OE}$ forma, first in time, earliest, with citations from the NW Midlands and from the Wycliffite Bible, which may suggest that by the fourteenth century «former» had an archaizing register.

${ }^{18}$ In the first edition there is no «moyen âge» except in the sense of «autheur du moyen âge» - and he writes in Latin. Law and history, or philosophy and literature. See also Charles Du Cange, Glossarium ad Scriptores Mediae et Infimae Latinitatis (1678).

${ }^{19}$ Visual evidence is, however, particularly intriguing where architecture is concerned, since there is clearly a stylistic convention which we call Tudor Gothic.

${ }^{20}$ Shakespeare's Festive World: Elizabethan Seasonal Entertainment and the Professional Stage, trans. Janet Lloyd, Cambridge, Cambridge University Press, 1991 [orig. Shakespeare et la fête, 1981], esp. chapt. 7.

${ }^{21}$ The Harvard Concordance to Shakespeare, Cambridge, Belknap Press, 1973. Montaigne writes of history «en ce genre d'estude des Histoires, il faut feuilleter sans distinction toutes sortes d'autheurs, et vieils, et nouveaux, et baragouins et Francois...» and speaks of the excellence of Froissart without distinguishing his period, as he does with Philippe de Commynes («qui reluit és 
anciens de leur sorte, comme au Sire de Joinville... Eginhart...»), II.10 «Des Livres».

22 «land / Until four hundred one and twenty years» (1.2.57), «year of our redemption / Four hundred twenty-six» (I.2.60-1), «river sala in the year eight hundred five» (I.2.64) ; also I.2.57, «eleventh year of the last king» (I.1.2).

${ }^{23}$ As Judith Maltby, among other historians, has recently stressed in work on the slow modification of «Old Church» practices. Here, too, there is gradualism rather than strong periodization. I am grateful to have been able to read her forthcoming «Prayer Book Protestantism in the 1640s-50s», Studies in Church History, ed. Robert Swanson (2002) in typescript.

${ }^{24}$ I quote from the edition of Lois Potter for Arden ${ }^{3}$, London, 1997 ; she thinks the prologue is Shakespeare's. Eugene M. Waith's Oxford edition, 1987, concurs. Dr Gordon McMullan considers that the section which follows this quotation «may be a form of occupatio, but it seems to be to exhibit a degree of anxiety which is due to a particular conjunction of historicity and Englishness, i.e. an anxiety which would not be produced in the same way by a more recent foreign writer» (p.c.). I am grateful to Dr McMullan not only for a careful reading of this paper, but also for allowing me to read the introduction to his forthcoming edition of Henry VIII.

${ }^{25}$ ldeas of collaboration vary, and I do not think we will ever know who, precisely, is responsible for what. Although most scholars name Fletcher as Shakespeare's collaborator, Jonathan Hope believes the prologue to be George Wilkins', in The Authorship of Shakespeare's Plays : a socio-linguistic study, Cambridge, Cambridge University Press, 1994, but the prologue contains a shortage of telltale markers such as auxiliary «do», and there are stylistic reasons (archaizing) to make it unlike Shakespeare, Wilkins, or Fletcher.

${ }^{26}$ As does the Arden ${ }^{2}$, ed F. D. Hoeniger, London, 1963.

27 «The essence of custom was that it was immemorial, and the argument could with equal facility be used that, since the people retained a given custom through many centuries, it had proved itself apt to meet all the emergencies which had arisen during that period. Custom was tam antiqua et tam nova, always immemorial and always perfectly up-to-date» (Ancient Constitution, p. 15).

${ }^{28}$ Hope, Authorship, p. 67-83.

${ }^{29}$ I am grateful to the English department of Jadavpur University for an invitation to spend a fortnight as their DSA Fellow in 2001, and for the opportunity to test the ideas in this paper at a lively Renaissance Seminar, in the course of which Prof. Choudhury made this observation.

${ }^{30}$ As Judith Maltby puts it (p.c.), there is no conversion moment, as may be seen from the arguments of John Jewel in 1587, An Apology for the Church of England, ed. John Booty (Washington, 1963). Rather, contemporary arguments themselves revolved around the question of continuity / discontinuity. See her Prayer Book and People in Elizahethan and Early Stuart England, Cambridge 
Studies in Early Modern British History (Cambridge, Cambridge University Press, 1998).

${ }^{31}$ I am grateful to the Rev. Dr. Judith Maltby and Prof. Wallace McCaffery for their help with the historiographical problem, to Prof. Jean-Claude Thiollier for advice on French philology, and, as always, to Prof. Stefan Collini for careful reading of the text. 